\title{
ESTIMASI KEBUTUHAN KADAR PROTEIN OPTIMAL UNTUK PERTUMBUHAN BENIH IKAN TAWES (Puntius gonionotus)
}

\author{
( Nengah Sweta Rabegnatar") dan Evi Tahapari")
}

\begin{abstract}
ABSTRAK
Salah satu masalah yang dihadapi dalam upaya penyediaan benih ikan tawes dalam jumlah yang cukup dan berlanjut adalah belum tersedianya pakan buatan yang bermutu tinggi dan ekonomis bagi benih ikan tawes. Untuk pembuatan pakan yang bermutu tinggi diperlukan informasi kebutuhan nutrien, antara lain kebutuhan proteinnya.Tujuan penelitian adalah untuk mengestimasi kebutuhan kadar protein pakan optimal untuk pertumbuhan (pembentukan protein tubuh dan pertumbuhan bobot) benih ikan tawes dalam budi daya keramba jaring apung. Benih berukuran rata-rata $2,27 \pm 0,18 \mathrm{~g}$ digunakan dengan padat tebar $100 \mathrm{ekor} / \mathrm{m}^{3}$. Pakan penelitian terdiri enam jenis yang berbeda kadar proteinnya yakni $20 \%, 25 \%, 30 \%, 35 \%, 40 \%$, dan $45 \%$ (dari campuran bahan pakan) dengan kombinasi kasein dan gelatin (4:1) sebagai protein pakan. Pemberian pakan berlangsung 59 hari dengan jumlah pemberian pakan berlebih. Hasil penelitian menunjukkan bahwa kadar protein pakan optimal untuk pertumbuhan benih ikan tawes adalah $41,78 \%$. Pada kadar protein pakan optimal tercapai kadar protein tubuh maksimal $(13,75 \%)$ dan pertambahan bobot rata-rata benih 4,56\%/hari (bobot benih 3,69 kali semula/59hari). Bobot benih terus meningkat dengan peningkatan kadar protein pakan sampai kadar protein pakan $45 \%$. Pertambahan bobot benih pada kadar protein pakan lebih dari $41,78 \%$ disebabkan oleh peningkatan kadar air tubuh (kadar protein tubuh dan kadar abu tubuh tidak berubah nyata, kadar lemak tubuh menurun). Sintasan benih yang berkisar antara 51,58\%-66,05\% tidak berbeda nyata $(P>0,1)$ antar jenis pakan. Kematian benih yang ada disebabkan oleh faktor yang terkait dengan penanganan.
\end{abstract}

ABSTRACT: Estimation of the optimal dietary protein requirement for growth of java carp fry (Puntius gonionotus). By: I Nengah Sweta Rabegnatar and Evi Tahapari

One of the contraints facing the attempt in providing an adequate and continuous seed supply to support comercial, large scale, and sustained development of java carp culture in Indonesia is the unavailability of high quality and economical artificial feed for the fry. Development of a high quality fish feed requires information on the nutrien requirement of the fish, among other the protein requirement. The objective of this research was to estimate optimal dietary protein requrement for growth (increase in body weight and body protein) of java carp fry reared in floating net cages. The fry used were $2.27 \pm 0.18 \mathrm{~g}$ in average and weight, stocked at $100 \mathrm{fry} / \mathrm{m}^{3}$. Six dietary treatments were used differing only in their protein contents namely 20\%,25\%,30\%,35, $\%, 40 \%$, and $45 \%$ of feed mixture using a combination of casein and gelatin (4:1) as the protein source. The fry were fed daily in excess for 59 days. It was found that the optimal dietary content for growth of the fry was $41.78 \%$ giving maximum body protein content (13.75\%) and average individual body weigt gain of $4.56 \%$ /day (fry average weight was 3.69 times the initial weight). Average weight gain of the fry increased with increasing dietary protein contents from $20 \%$ to $45 \%$, but the increase in weight gain at dietary protein contents higher than the optimal content $(41.78 \%)$ was due to the increase in body water content (body protein and ash concentrations did not change significantly, body lipid content decreased). Survival rates of the fry $(51.85 \%-66.0 \%)$ were not significantly different $(P>0.05)$ among treatments, while fry mortality was due to factors related to fry handling.

KEYWORDS: feed, dietary protein requirement, java carp, Puntius gonionotus, fry rearing

\section{PENDAHULUAN}

Di Indonesia, ikan tawes merupakan ikan budi daya tradisional ekonomis penting dengan produksi budi daya secara nasional di urutan kedua atau ketiga bersama mujair setelah ikan mas (Anonim, 1989).
Ikan tersebut telah dibudidayakan dalam keramba jaring apung di Jawa Tengah serta di Asia Tenggara (Dalmendo, 1980). Ikan tawes menguntungkan budi daya tradisional karena merupakan herbivora (Bardach et al., 1972; Varikul, 1980; Tjahjo, 1991); dapat tumbuh di air tawar dan payau (Mubarak, 1988; Arsad

\footnotetext{
·) Peneliti pada Balai Penelitian Perikanan Air Tawar, Sukamandi
} 
\& Hardini, 1989); mudah dibiakkan (Suseno, 1983) berpotensi sebagai donor hipofisis (Varikul, 1980); mudah beradaptasi terhadap makanan tambahan (Ardiwinata, 1971; Arsad \& Hardini, 1989; Varikul, 1980).

Bagi ikan budi daya yang ekonomis, perlu diketahui kebutuhan nutriennya sebagai pedoman untuk permbuatan pakan yang efisien, ekonomis, dan ramah lingkungan. Salah satu kebutuhan nutrien yang perlu segera diketahui adalah protein dalam pakan. Protein dibutuhkan untuk perawatan tubuh dan pertumbuhan, terutama pada benih dan ikan muda dalam fase pertumbuhan. Untuk pembuatan pakan yang bermutu tinggi, efisien, dan ekonomis, protein pakan perlu diperhitungkan dengan tepat karena merupakan komponen termahal. Dalam bangunan tubuh ikan, protein merupakan komponen terbesar sesudah air ( Lagler et al., 1977; Stickney, 1979; NRC, 1983). Ikan menyintesis protein tubuh dari protein pakan yang mutunya memenuhi syarat sehingga kadar protein pakan yang dibutuhkan relatif tinggi dan komposisi asam aminonya harus sesuai dengan kebutuhan sintesis protein tubuh. Kebutuhan kadar protein dalam pakan antara lain bergantung pada jenis dan ukuran ikan, mutu protein pakan, energi, dan komposisi pakan secara keseluruhan serta kesuburan perairan budi daya. Karena banyak faktor, informasi kebutuhan protein dalam pakan yang dilaporkan dalam literatur amat bervariasi, 25\%-50\% (Lovell, 1988). Informasi kebutuhan protein yang tepat untuk suatu spesies dan ukuran ikan tertentu dan kondisi perairan tertentu harus diperoleh melalui penelitian. Informasi kebutuhan nutrien benih ikan tawes belum cukup tersedia.

Tujuan penelitian adalah untuk mengestimasi kebutuhan protein optimal dalam pakan untuk pertumbuhan benih tawes berukuran sekitar $2 \mathrm{~g}$ dalam budi daya keramba jaring apung.

\section{BAHAN DAN METODE}

Penelitian dilakukan dalam keramba jaring apung dengan ukuran $1 \mathrm{~m} \times 1 \mathrm{~m} \times 1,5 \mathrm{~m}$; di Danau Lido-Bogor, memakai benih ikan tawes berukuran 2,27 $\pm 0,18 \mathrm{~g}$. Percobaan menggunakan rancangan acak kelompok dengan tiga kelompok searah dan kira-kira tegak lurus terhadap aliran air danau. Pengelompokan ini untuk mencegah pengaburan pengaruh pakan oleh kemungkinan perbedaan pengaruh kelompok air setelah penebaran benih dan pemberian pakan. Padat tebar benih tawes $100 \mathrm{ekor} / \mathrm{m}^{3}$. Keenam pakan perlakuan berbeda kadar proteinnya yakni $20 \%, 25 \%$, $30 \%, 35 \%, 40 \%$, dan $45 \%$ (dari bobot campuran bahan pakan), memakai kombinasi protein kasein dan gelatin (4:1) sebagai protein pakan (NRC, 1983). Pakan diberikan pada benih berupa krambel selama 59 hari dengan jumlah pemberian harian (\%) berlebih dan sama untuk semua perlakuan. Dalam periode makan pertama (17 hari) jumlah pakan harian adalah 15\% dari bobot benih yang ditebar; dalam periode kedua (3 minggu) 15\% untuk minggu pertama dan 20\% dua minggu berikutnya dari bobot benih pada akhir periode pertama. Dalam periode akhir (3 minggu) seperti periode kedua tetapi persentasenya berdasarkan bobot benih pada akhir periode kedua. Jatah pakan harian diberikan pada ikan dua kali, masing-masing setengah bagian pada pukul 09.00 dan 13.00 WIB. Untuk memelihara kebersihan keramba jaring apung maka tumbuhan penempel pada dinding keramba selama percobaan disikat setiap 7-10 hari.

Bobot, jumlah, dan keadaan fisik luar benih diamati pada akhir dari ketiga periode pemberian pakan. Kadar protein dan komposisi proksimat tubuh benih dianalisis pada awal dan akhir percobaan. Sebagai data penunjang dan deskripif dilakukan analisis komposisi asam amino protein pakan (kasein dan gelatin) dan benih tawes pada awal percobaan serta kualitas air.

Analisis statistik dilakukan terhadap data kadar protein dan komponen proksimat lain tubuh, pertambahan bobot rataan benih, dan sintasan benih setelah mempertimbangkan keperluan transformasi data dan variabilitas lapangan (Shell, 1983; Sokal \& Rohlf, 1973; Steel \& Torrie, 1960). Uji beda nyata pengaruh pakan (kadar protein) dilakukan dengan uji DNMRT (Steel \& Torrie, 1960). Estimasi kadar protein pakan optimal untuk pertumbuhan dan sintasan benih dilakukan berdasar hubungan regresi antara parameter benih (pertumbuhan bobot rata-rata, kadar protein, dan komponen proksimat yang lain dan kadar protein pakan dengan model hubungan polinomial ortogonal yang dikemukakan Anderson \& Houseman (1942) dan Bancroft (1968).

Untuk menghitung penambahan bobot rataan digunakan rumus seperti di bawah ini:

$$
\text { PBR }=\frac{\text { BR akhir }(g)-B R \text { awal }(g)}{B R \text { awal } \times 59} \times 100 \%
$$

Keterangan: PBR : Penambahan bobot rataan

BR : Bobot rata-rata 
HASIL DAN BAHASAN

\section{Kualitas air}

Kualitas air budi daya selama percobaan (Tabel 1) memenuhi syarat untuk mendukung kehidupan nor- pembusukan sisa pakan, kotoran ikan, dan ekskresi sisa metabolisme. Pertumbuhan bobot rataan yang cukup tinggi ini juga menunjukkan bahwa benih tawes dapat menerima pakan percobaan dengan baik. Dengan demikian data pengamatan benih tawes yang diperoleh dapat diterima sebagai hasil respon benih

Tabel 1. Kualitas air masuk dan air dasar keramba (1 $\mathrm{m}$ di bawah permukaan) pada siang hari Table 1. Quality of inflow water and water of cages bottom (1 $\mathrm{m}$ below the surface) in day time

\begin{tabular}{|c|c|c|c|c|}
\hline $\begin{array}{c}\text { Air contoh } \\
\text { Water samples }\end{array}$ & $\begin{array}{c}\text { Oksigen terlarut } \\
\text { (mg/L) } \\
\text { Dissolved oxygen } \\
\text { (mg/L) }\end{array}$ & $\mathrm{pH}$ & $\begin{array}{c}\text { Karbondioksida } \\
\text { (mg/L) } \\
\text { Carbondioxide } \\
\text { (mg/L) }\end{array}$ & $\begin{array}{c}\text { Amonia tak terionisasi } \\
\text { (mg/L) } \\
\text { Unionized ammonia, } \\
\mathrm{NH}_{3}(\mathrm{mg} / \mathrm{L})\end{array}$ \\
\hline $\begin{array}{l}\text { Air masuk pada awal dan } \\
\text { akhir percobaan } \\
\text { Inflow water at initial and } \\
\text { end of experiment }\end{array}$ & $5.3-6.6$ & 7 & $5.59-6.39$ & $0.01-0.02$ \\
\hline $\begin{array}{l}\text { Air dasar keramba } \\
\text { selama percobaan * } \\
\text { Water of cage bottom } \\
\text { during experiment }{ }^{*}\end{array}$ & $6.04 \pm 0.8^{*}$ & 7 & $5.69 \pm 0.53^{*}$ & $0.01 \pm 0.00^{*}$ \\
\hline
\end{tabular}

"Nilai rataan dan simpangan baku

"Mean and standard deviation

mal ikan pada umumnya seperti dikemukakan Boyd (1979). Benih ikan tawes hidup normal dalam air ini dapat mencapai laju pertumbuhan bobot rataan $5,14 \% /$ hari (Tabel 2 ) atau ukurannya menjadi 4,0 kali tawes yang normal terhadap perlakuan (pakan) yang diteliti.

Air masuk selama percobaan mempunyai suhu rataan dan simpangan baku $26,8 \pm 0,09^{\circ} \mathrm{C}$ dan

Tabel 2. Bobot rata-rata, pertambahan bobot rataan, dan sintasan benih ikan tawes setelah 59 hari pemberian pakan

Table 2. Means of individual weight, weight gains, and survival rates of the fish after 50 days of feeding

\begin{tabular}{cccc}
\hline $\begin{array}{c}\text { Pakan perlakuan } \\
\text { Dietary treatments }\end{array}$ & $\begin{array}{c}\text { Bobot rata-rata (g) } \\
\text { Harvest weight (g) }\end{array}$ & $\begin{array}{c}\text { Pertambahan bobot } \\
\text { rataan (\%hari) } \\
\text { Weight gain (\%day) }\end{array}$ & $\begin{array}{c}\text { Sintasan (\%) } \\
\text { Survival rate (\%) }\end{array}$ \\
\hline A (20\% protein) & $7.10 \pm 0.44$ & $3.63 \pm 0.40^{\mathrm{a} *}$ & $61.11 \pm 21.36^{\mathrm{ab} *}$ \\
B (25\% protein) & $8.47 \pm 0.80$ & $4.54 \pm 0.23^{\mathrm{bc}}$ & $54.94 \pm 10.69^{\mathrm{a}}$ \\
C (30\% protein) & $7.99 \pm 0.82$ & $4.06 \pm 1.11^{\mathrm{ab}}$ & $66.05 \pm 4.28^{\mathrm{b}}$ \\
D (35\% protein) & $8.14 \pm 0.28$ & $4.64 \pm 0.53^{\mathrm{bc}}$ & $51.85 \pm 20.37^{\mathrm{a}}$ \\
E (40\% protein) & $8.21 \pm 0.95$ & $4.24 \pm 0.70^{\mathrm{ab}}$ & $58.64 \pm 4.66^{\mathrm{ab}}$ \\
H (45\% protein) & $8.54 \pm 1.36$ & $5.14 \pm 0.59^{\mathrm{cd}}$ & $57.41 \pm 19.24^{\mathrm{ab}}$ \\
\hline
\end{tabular}

* Nilai rata-rata diikuti huruf yang sama dalam kolom yang sama, tidakmenunjukkan perbedaan pada taraf nyata $(P>0,01)$

* Value in columns followed by the same superscript are not significantly different $(P>0.01)$

ukuran awal/59 hari. Kualitas air masuk dan yang di dasar keramba jaring apung tidak berbeda. Hal ini menunjukkan bahwa pergantian air dalam keramba oleh air masuk berjalan baik sehingga tidak terjadi penurunan kualitas air akibat pernapasan ikan, kecerahan Secchi $206 \pm 9 \mathrm{~cm}$. Air di danau tampak kehijauan karena kandungan fitoplankton tetapi warna air contoh setebal $1 \mathrm{~m}$ bening (tidak kehijauan). Selama percobaan cuaca umumnya cerah, kadang mendung atau hujan selama tak lebih dari satu jam. 


\section{Sintasan benih tawes}

Sintasan benih berkisar 51,85\%-66,05\% (Tabel 2 dan Gambar 1). Kisaran sintasan ini cukup baik bagi benih ikan tawes dalam lingkungan terbuka karena benih tawes peka terhadap gangguan lingkungan. Kematian benih terutama akibat faktor-faktor yang terkait dengan penanganan saat penimbangan berkala
Kebutuhan minimal kadar potein pakan untuk perawatan benih tawes ini adalah kurang dari $20 \%$. Berdasarkan data pertambahan bobot rata-rata (Tabel 2 dan Gambar 2, 3a) kadar protein pakan $10 \%$ untuk sintasan layak dikaji. Dengan demikian disimpulkan bahwa perubahan kadar protein pakan dalam kisaran 20\%-40\% tidak berpengaruh terhadap sintasan benih. Sedangkan untuk peningkatan nilai sintasan

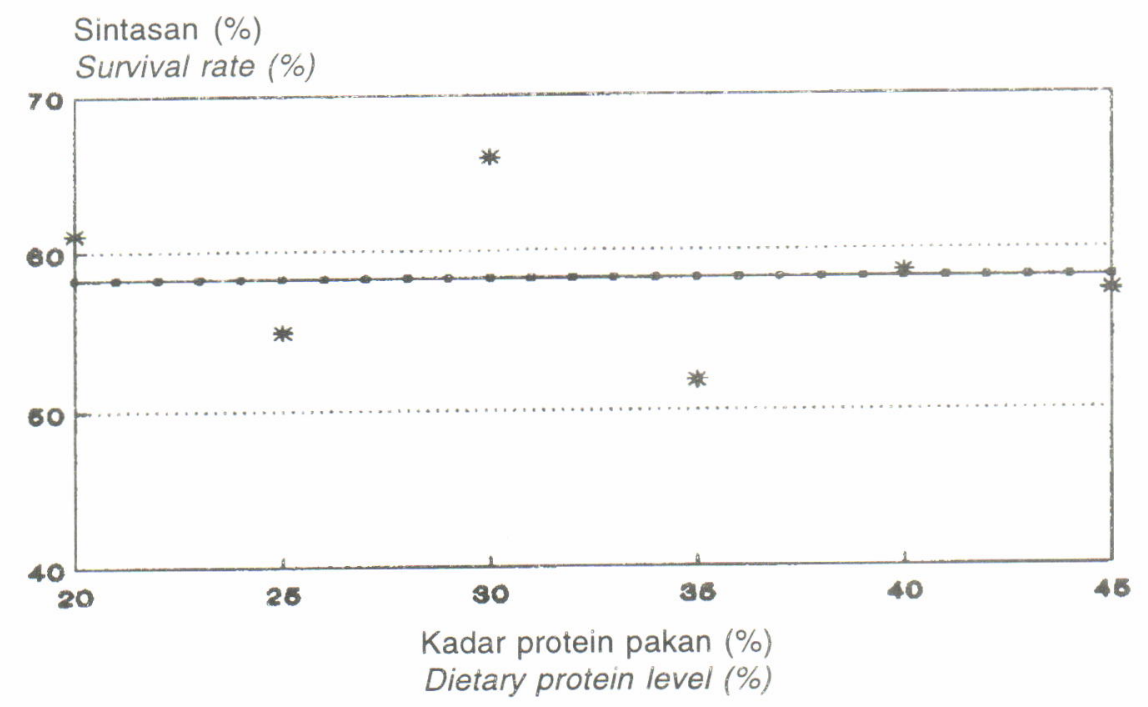

Gambar 1. Regresi sintasan benih ikan tawes $(\mathrm{Y})$ terhadap kadar protein pakan $(\mathrm{X})$ tidak berbeda nyata $(P>0,10) .{ }^{*}=$ nilai rataan pengamatan

Figure 1. Regression of fish survival rate $(Y)$ on dietary protein level $(X)$ are not significantly $(P>0.10){ }^{*}=$ means of data

yaitu pada penimbangan pertama sintasan tinggi tetapi pada penimbangan berikutnya menurun. Faktor lingkungan ini tidak mempengaruhi hasil uji beda nyata antar perlakuan (pakan) karena faktor lingkungan yang sama berlaku pada semua perlakuan dan mempengaruhi kuantitas sintasan tetapi tidak mempengaruhi beda sintasan antar pakan.

$\mathrm{Hal}$ ini sesuai dengan dasar hubungan antara sintasan dan kebutuhan protein untuk kehidupan ikan, yakni bahwa untuk mempertahankan keadaan tubuh dan kehidupan normal hanya dibutuhkan kadar protein dan nutrien lain, pakan yang cukup untuk perawatan (memperbaharui sel-sel tubuh yang aus), energi metabolisme standar, energi aktivitas harian, dan energi panas akibat metabolisme (Smith, 1980); tanpa memerlukan pertambahan bobot.

Evaluasi sintasan antar pakan di atas menunjukkan bahwa kebutuhan protein untuk perawatan benih tawes berukuran 2,27 g telah terpenuhi pada pakan dengan kadar protein $20 \%$ dan pada pakan ini tawes telah mencapai pertambahan bobot yang berarti (Tabel 2) dan peningkatan kadar protein tubuh dibanding benih awal percobaan. diupayakan dengan mengoptimalkan pengelolaan faktor lingkungan antara lain dengan meminimalkan penanganan benih secara fisik.

\section{Pertambahan Bobot dan Komponen Proksimat Benih Tawes}

Tubuh ikan tersusun dari komponen proksimat: air, protein, lemak, karbohidrat, dan mineral yang dinyatakan dengan abu tubuh, air, dan protein secara kuantitatif sebagai komponen terbesar (Stickney, 1979; NRC, 1983). Dua jenis pakan yang mutunya berbeda mungkin menghasilkan pertambahan bobot rataan ikan yang sama tetapi komposisi proksimatnya akan berbeda atau sebaliknya. Protein atau asam amino dalam pakan merupakan bahan untuk sintesis protein tubuh. Protein berlebih atau bermutu rendah tidak dapat digunakan untuk sintesis protein tubuh, akan dioksidasi untuk energi, diubah menjadi lemak atau karbohidrat (NRC, 1983; Lovell, 1988). Perubahan kadar lemak umumnya diikuti perubahan air secara berlawanan (Lagler et al., 1977). Shearer (1994) menyimpulkan hal serupa pada ikan budi daya khususnya ikan salmon; a) kadar protein ikan salmon 


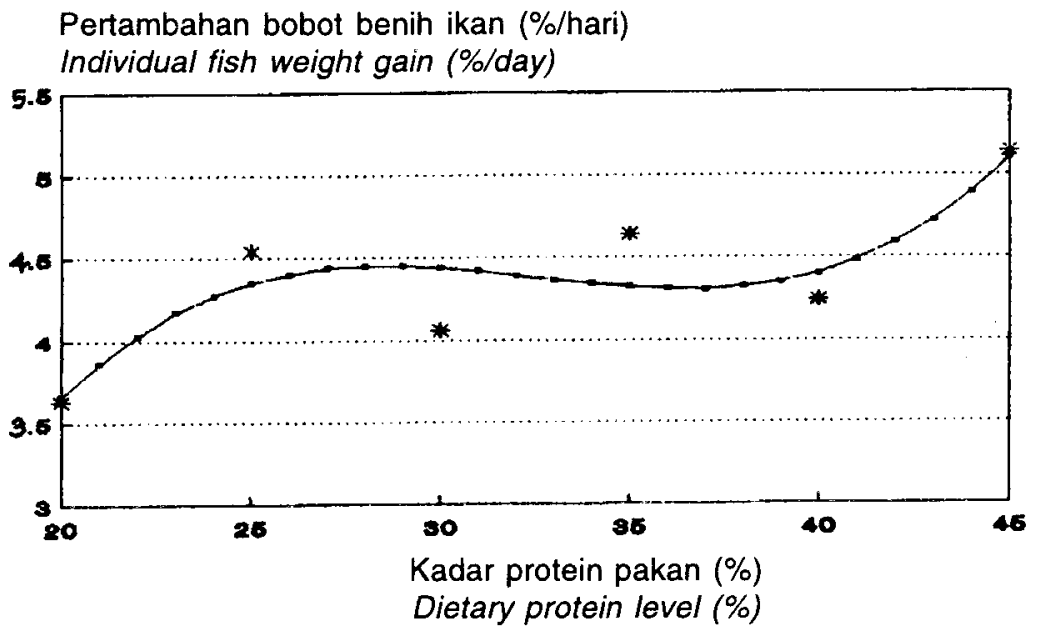

Gambar 2. Regresi laju pertambahan bobot rataan benih ikan tawes $((Y)$ terhadap kadar protein pakan $(X)$ nyata $(P<0,10)^{*}=$ nilai rataan pengamatan, $Y m a=Y$ maksimum, $Y m i=y$ minimum, $Y m a$ dan $Y m i$ tidak berbeda nyata

Figure 2. Regression of individual fish weight gain $(Y)$ on dietary protein level $(X)$ is significant $(P<0.10) .{ }^{*}=$ means of data, $Y m a=Y$ maximum, $Y m i=Y$ minimum. $Y m a$ and $Y m i$ are not significantly different $(P>0.10)$

yang dalam pertumbuhannya sepenuhnya ditentukan oleh ukuran ikan (faktor dalam), b) kadar lemak dipengaruhi faktor dalam maupun faktor luar, c) kadar abu tubuh dikontrol secara homeostatis, d) kadar air berhubungan terbalik dengan kadar lemak. Disebutkan juga bahwa perbandingan komposisi proksimat tubuh ikan dengan satuan persen dinyatakan berdasarkan bobot kering. Pengabaian perbedaan bobot awal ikan sebagai faktor kovarian kering akan menghasilkan kesimpulan keliru. Secara umum Strand (1976) mengemukakan bahwa tubuh hewan sebagai suatu sistem organisme, kegiatan metabolisme, dan fisiologi berlangsung secara terkontrol, terkoordinasi, dan terintegrasi. Jadi dengan adanya sistem kontrol pengaruh protein pakan dan komposisi proksimat pakan tidak selalu tercermin pada kadar protein dan komposisi proksimat tubuh ikan dengan tegas. Dalam percobaan pemberian pakan yang terkontrol diharapkan adanya penampakan perbedaan dalam pengaruh komposisi pakan yang lebih jelas, namun demikian pola hubungan komposisi pakan dengan komposisi proksimat tubuh dan pertumbuhan bobot rata-rata seperti di atas itu perlu dipertimbangkan selama evaluasi hasil percobaan ini.

Pemberian pakan percobaan dengan protein pakan $20 \%-45 \%$ menghasilkan pertumbuhan bobot rata-rata $3,63 \%-5,14 \%$ /hari (ukuran benih 3,14-4,03 kali ukuran awal/59 hari) (Tabel 2) dengan kadar protein, lemak, abu tubuh meningkat, dan air, karbohidrat menurun dibanding benih awal percobaan. Di antara keenam pakan, pertumbuhan bobot rata-rata tertinggi $(\mathrm{P}<0,05)$ dicapai pada pakan dengan protein pakan $45 \%$, tetapi kadar protein tertinggi $(P<0,01)$ pada protein pakan
$40 \%$, kadar lemak tertinggi $(P<0,01)$ pada protein pakan $40 \%$, air terendah $(P<0,01)$ pada protein pakan $40 \%$, kadar karbohidrat tertinggi $(P<0,01)$ pada protein pakan $40 \%-45 \%$, kadar abu tubuh tertinggi $(\mathrm{P}<0,01)$ pada protein pakan $30 \%-50 \%$ tetapi kisaran nilainya kecil. Tampak bahwa pertumbuhan bobot ratarata yang tinggi pada protein pakan $45 \%$ ini tidak diikuti oleh kadar protein, lemak, karbohidrat yang tinggi melainkan oleh kadar air dan abu tubuh yang tinggi. Hubungan regresi nyata $(P<0,10)$ terjadi antara pertumbuhan bobot rata-rata, protein, lemak, dan abu tubuh terhadap protein pakan, sedangkan bagi air dan karbohidrat tidak nyata. Kadar abu tubuh terkait dengan protein pakan melalui pertumbuhan yang meliputi juga pembentukan tulang, sisik, dan mineral lain (abu tubuh). Jadi pertumbuhan bobot rata-rata protein, lemak, dan abu tubuh lebih peka mengikuti pengaruh perubahan protein pakan dibandingkan air dan karbohidrat.

Hubungan regresi (Gambar 3a) menunjukkan bahwa peningkatan protein pakan pada kisaran 20$23,22 \%$ tidak mengubah protein tubuh dan baru dalam kisaran protein pakan $23,22-41,78 \%$ meningkatkan protein tubuh sampai protein maksimum 13,75\% pada protein pakan $41,78 \%$. Kemudian protein menurun pada protein pakan lebih dari $41,78 \%$. Jadi protein pakan optimal untuk protein pakan maksimum adalah 41,78 . Sebaliknya pertumbuhan bobot rata-rata telah meningkat dengan peningkatan protein pakan dalam kisaran $20-28,41 \%$ sampai mencapai pertumbuhan bobot rata-rata maksimum $4,45 \% /$ hari pada protein pakan $28,41 \%$ (Gambar 2), kemudian tidak berubah nyata dalam kisaran protein pakan $28,41-36,59 \%$ dan 


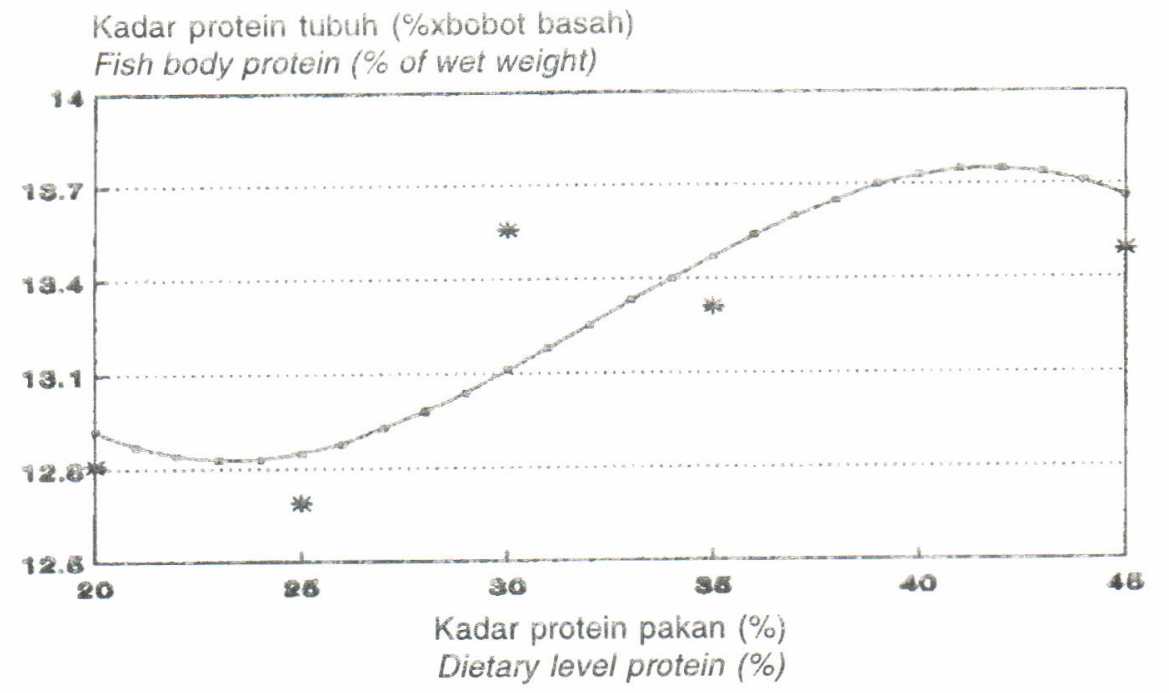

Gambar 3a.Regresi kadar protein tubuh benih ikan tawes terhadap kadar protein pakan $(X)$ nyata $(P<0,10),{ }^{*}=$ nilai rataan pengamatan, $Y m i=Y$ minimum, $Y$ ma maksimum, $Y$ pada $K=20 \%$ dan $Y$ mi tidak berbeda nyata, $Y$ ma dan $Y$ pada $X=45 \%$ berbeda nyata

Figure 3a. Regression of the fish body protein $(Y)$ on dietary protein level $(X)$ are significant $(P<0.10) .{ }^{*}=$ means of data, $Y m i=Y$ minimum, $Y$ ma $=Y$ maximum, $Y$ at $X=20 \%$ and $Y$ mi are not significantly different $(P>0.10)$, Yma and $Y$ at $X=45 \%$ are significantly different $(P<0.10)$

meningkat terus pada protein pakan $36,59-45 \%$ sampai pertumbuhan bobot rata-rata tinggi $5,10 \% /$ hari (ukuran benih tawes menjadi 4,10 kali ukuran awal/ 59/hari) pada protein pakan 45\% (Gambar 2). Pertumbuhan bobot rata-rata pada protein pakan lebih dari $45 \%$ tidak diungkap dalam percobaan ini. Pada protein pakan lebih dari $41,78 \%$ pertumbuhan bobot rata-rata tidak lagi disertai perubahan protein (Gambar 3a) dan abu tubuh (Gambar 3b), melainkan peningkatan air dan penurunan lemak (Gambar 3b). Pertumbuhan bobot rata-rata tinggi yang disertai tercapainya protein maksimum telah tercapai pada protein pakan $41,78 \%$. Peningkatan abu tubuh terjadi pada kisaran protein pakan 23,22 - 41,78 \% (Gambar 3c). Sedangkan peningkatan pertumbuhan bobot ratarata pada protein pakan lebih dari $41,78 \%$ (Gambar 2) tidak disertai peningkatan protein tubuh (Gambar 3a) dan abu tubuh (Gambar 3b) melainkan

Kadar lemak tubuh (\% bobot basahi)

Fish body fat level (\% of wet weight)

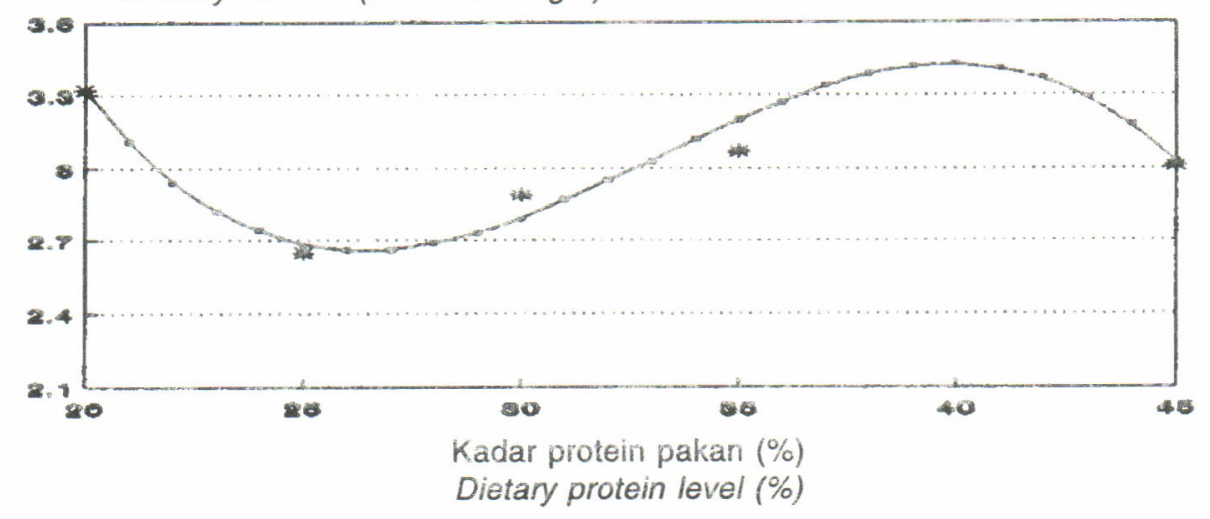

Gambar 3b. Regresi kadar lemak tubuh ikan tawes $(Y)$ terhadap kadar protein pakan $(X)$ nyata $(P<0,10){ }^{*}=$ nilai rataan pengamatan. $Y$ pada $X=20$ dan $Y$ mi berbeda nyata, $Y$ ma dan $Y$ pada $X=45$ berbeda nyata

Figure 3b. Regression of fish body fat level $(Y)$ on dietary protein level $(X)$ are significant $(P<0.10)$, ${ }^{*}=$ means of data, $Y$ at $X=20 \%$ are $Y$ ini are significantly different, $Y$ ma and $Y$ at $X=45 \%$ are significantly different 
peningkatan air yang melebihi penurunan lemak (Gambar $3 b$ ). Pada protein pakan $41,78 \%$ ini diperkirakan pertumbuhan bobot rata-rata berdasar persamaan regresi (Gambar 2) ialah 4,56\%/hari (ukuran ikan menjadi 3,69 kali ukuran awal). Berdasarkan hasil uji beda nyata pada Tabel 2, pertumbuhan bobot rata-rata $4,45 \% /$ hari pada protein seimbang, tanpa makanan alami) seperti dilaporkan Lim (1988).

Protein pakan dalam percobaan ini mempunyai komposisi asam amino khususnya asam amino benih ikan tawes yang digunakan, kecuali arginin. Jadi masih terdapat peluang untuk meningkatkan mutu protein pakan percobaan ini dengan meningkatkan kadar

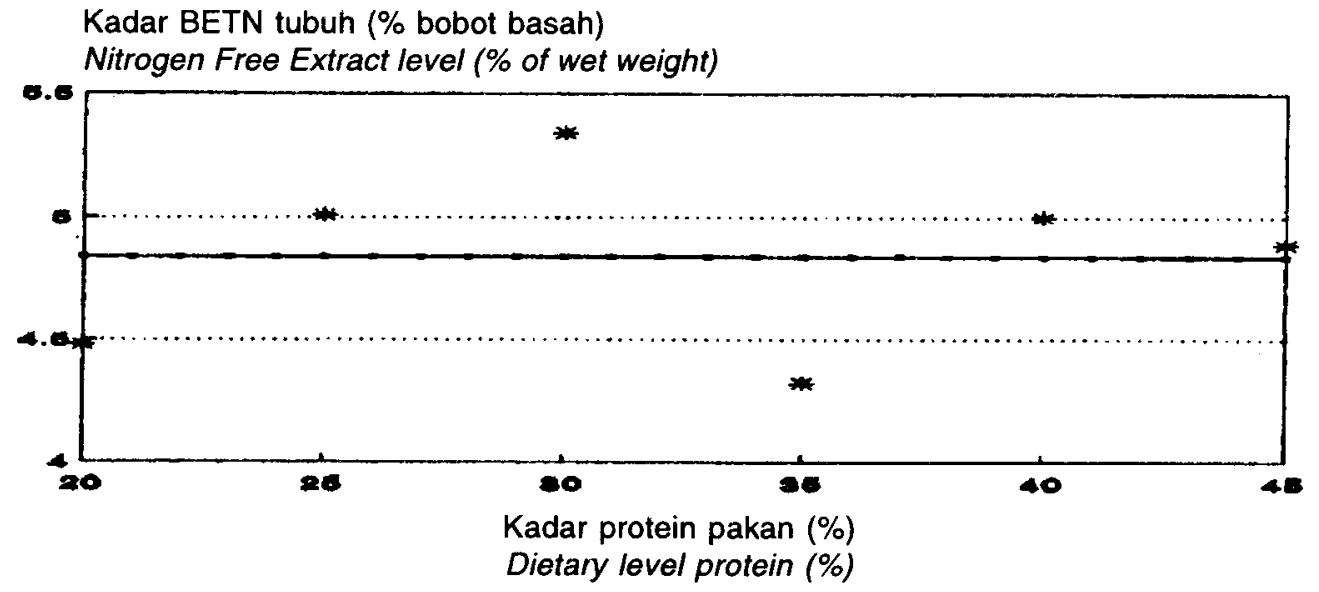

Gambar 3c. Regresi kadar karbohidrat tubuh *BETN) benih ikan tawes $(Y)$ terhadap kadar protein pakan (X) tidak nyata $\left(P>0,10 .{ }^{*}=\right.$ nilai rataan pengamatan

Figure 3c. Regression of fish body carbohydrate (Nitrogen Free Extract) level $(Y$ ) on dietary protein level $(X)$ are not significant $(P>0.10) .{ }^{*}=$ means of data

pakan 28,41 dan pertumbuhan bobot rata-rata $4,56 \%$ / hari pada protein pakan $41,78 \%$ ini tidak berbeda nyata. Jadi protein pakan optimal untuk pertumbuhan bobot rata-rata maksimum yang disertai peningkatan protein ialah $28,41 \%$; tetapi protein yang dicapai belum maksimum yakni $13,00 \%$ (berdasar persamaan regresi maksimum Gambar 3a). Dengan demikian protein pakan optimal untuk pertumbuhan bobot rata-rata tertinggi yang disertai protein maksimum ialah $41,78 \%$ karena protein tubuh $12,0 \%$ pada protein pakan $28,41 \%$ dan protein tubuh maksimum $13,75 \%$ pada protein pakan optimal $41,78 \%$ ini berbeda nyata (Tabel 2).

Protein pakan optimal $41,78 \%$ ini tidak jauh berbeda dari kebutuhan protein ikan grass carp (Ctenopharyngodon idella) muda yang herbivora: 41 $43 \%$ (protein pakan kasein), bandeng: $40 \%$ (kasein), dan pada kebutuhan protein (lebih tinggi) untuk ikan omnivora, misalnya ikan mas: $31-38 \%$ (kasein); lebih rendah dari karnivora misalnya sidat (Anguilla japonica): $45,5 \%$ (kasein + arginin + sistein) seperti dikemukakan dalam NRC (1983); lebih rendah dari kebutuhan benih lele berukuran sekitar $1 \mathrm{~g}: 45,38 \%$ (kasein + protein tepung ikan 5,35:1) seperti dilaporkan Rabegnatar \& Praseno (1993) dan kebutuhan ikan planktivora misalnya Oreochromis sp. yang mendekati $50 \%$ (protein dengan komposisi arginin. Walaupun demikian, mutu protein pakan ini cukup tinggi karena menghasilkan kadar protein tubuh maksimum $13,75 \%$ sedangkan sel hewan umumnya terdiri atas $12-14 \%$ protein (Strand, 1976). Air media budi daya tidak mengandung tumbuhan air berdaun (keramba disikat tiap 7-10 hari) dan kandungan fitoplankton rendah (kecerahan secchi $206 \mathrm{~cm}$ ). Karena itu protein pakan optimal benih tawes masih mungkin dikurangi dari $41,78 \%$ dengan memakai protein dengan komposisi asam amino minimal seperti protein pakan ini, tetapi dengan kadar arginin lebih tinggi dari $9,3 \%$ dari kadar protein pakan atau dengan membudidayakan benih tawes dalam perairan yang cukup makanan alami tetapi padat tebar semi-intensif.

\section{KESIMPULAN}

1. Kadar protein pakan optimal untuk pertumbuhan bobot tertinggi yang disertai kadar protein tubuh maksimal adalah $41,78 \%$ dari bobot campuran bahan pakan, sedang kadar protein pakan optimal untuk pertambahan bobot maksimal adalah $28,41 \%$. Pada kondisi percobaan, pada kadar protein pakan $28,41 \%$ tercapai kadar protein tubuh $13,00 \%$ dan pertambahan bobot benih $4,45 \%$ /hari; sedangkan kadar protein pakan $41,78 \%$ tercapai kadar protein tubuh maksimal $13,75 \%$ dan pertambahan bobot benih 4,56\%/hari (ukuran bobot 


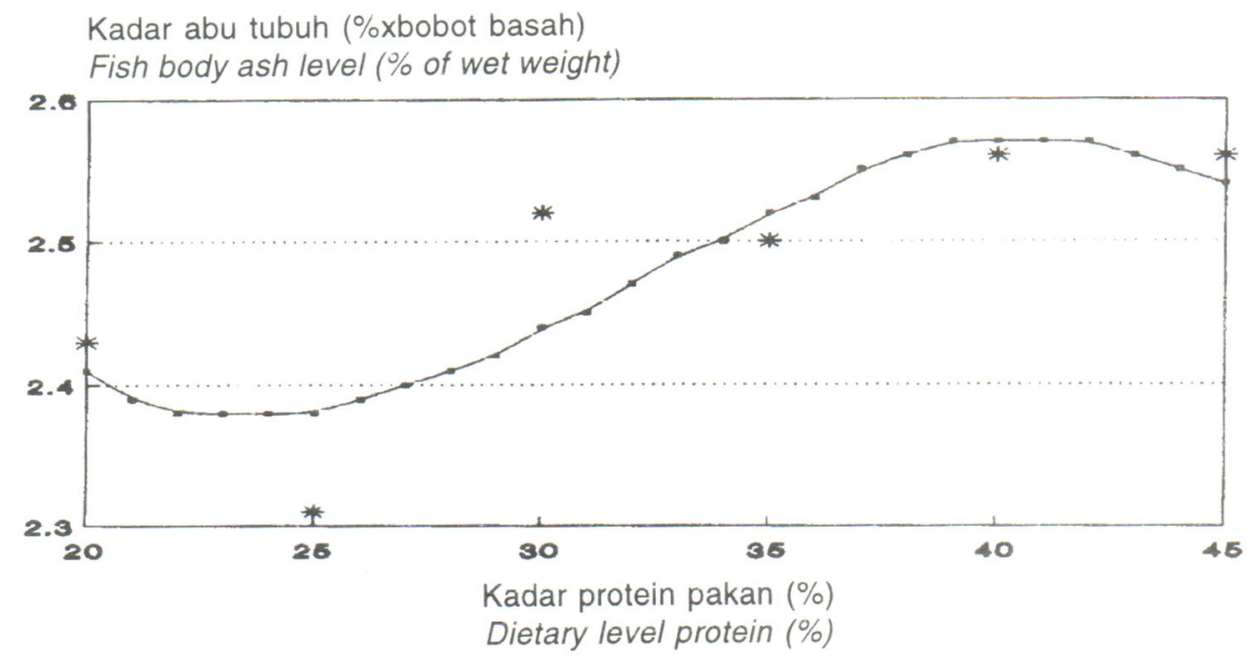

Gambar 3d.Regresi kadar abu tubuh benih ikan tawes $(Y)$ terhdap protein pakan $(X)$ nyata $(P<0,10) .{ }^{*}=$ nilai rataan pengamatan, $Y$ mi $=Y$ minimum, $Y m a=Y$ maksimum. $Y$ ma dan $Y$ pada $X=45 \%$ tidak berbeda nyata

Figure 3d. Regression of fish body ash level $(Y)$ on dietary protein level $(X)$ are significant $(P<0.10) .{ }^{*}=$ means of data, $Y m=Y$ minimum, $Y m a=Y$ maximum, $Y m a$ and $Y$ at $X=45 \%$ are not significantly different $(P>0.10)$

benih menjadi 3,69 kali semula/59 hari). Pada kadar protein pakan lebih dari $41,78 \%$ pertambahan bobot benih masih meningkat tetapi tidak disertai perubahan nyata kadar protein dan abu tubuh melainkan oleh peningkatan kadar air tubuhnya melebihi penurunan kadar lemak tubuh.

2. Kadar protein pakan $20 \%$ telah lebih dari kebutuhan untuk kehidupan sehat benih tawes saja (sintasan). Pada kondisi percobaan ini sintasan benih 51,85$66,05 \%$. Kematian benih tidak disebabkan pakan (sebagai nutrien) melainkan faktor yang terkait dengan kepekaan benih terhadap penanganan.

\section{DAFTAR PUSTAKA}

Anderson, R.L. and E.E. Housemam. 1942. Tables of orthogonal polynomial values extended to $\mathrm{N}=104$. Res.Bull. 297 April. 1942. Ames, lowa. Agricultural Experiment Station, lowa Stale College of Agricultural, and Mechanic Arts. p. 597-611.

Anonim. 1989. Statistik Perikanan Indonesia 1987. Jakarta, Direktoral Jenderal Perikanan. 10 pp.

Anonim. 1994. Buku Tahunan 1992. Statistik Perikanan Tingkat Propinsi Semarang, Jawa Tengah. p. 184191.

Ardiwinata, R.O. 1971. Pemeliharaan Ikan. Jilid 2. Pemeliharaan Tawes (Bader, putihan, Dj). Cetakan ke-3. Bandung, Sumur Bandung. p. 29-32.

Arsad, H. dan R.E Hardini. 1989. Petunjuk Praktis Budidaya Perikanan (suatu rangkuman). Jakarta, PD. Mahkota. p. 77-86.

Bancroft, T.A. 1968. Topics in Intermediate Statistical Methods. Vol one. Ames, lowa. The lowa State University Press. p. 87-94.
Bardach, J.E., Ryther, and W.O. Mclarney. 1972. Aquaculture. New York. Wiley Interscience. p. 102-104.

Boyd, C.E. 1979. Water Quality in Warmwater Fish Pond. Auburn. Alabama. Auburn University. p. 70-72.

Dalmendo, M.M. 1980. Present Status of Aquaculture Technology in South East Asia. Pros. Lok. Nas. Teknologi Tepat Guna Bagi Pengembangan Perikanan Budidaya Air Tawar. Bogor, 28-31 Januari 1980, Balai Penelitian Perikanan Air Tawar. p. 319141.

Lagler, K.F., J.E. Bardach, R.R. Miller, and D.R. May Passino. 1977. Ichthyology. New York, John Willey and Sons. p. 153-163.

Lim, C. 1988. Practical Feeding-Tilapias. In. Lovell, T. eds. 1988. Nutrition and Feeding of Fish. New York, Van Nostrabd Reinhold. p. 163-183.

Lovell, T. 1988. Nutrition and Feeding of Fish. New York, Van Nostrand Reinhold. p. 13-29.

Mubarak, A.A. 1988. Sedikit mengenal biologi ikan tawes. Majalah Dinas Perikanan Propinsi Daerah TK. I Jawa Tengah. No.4/Th. II/1988. p. 35-36.

NRC (National Research Council). 1977. Nutrient Requrement of Warmwater Fishes. Washington, D.C., National Academy of Sciences. p. 85-86.

NRC (National Research Council). 1983. Nutrient Requirement of Warmwater Fishes and Shellfishes. Washington, D.C., National Academy of Sciences. p. 2-6; 50-52.

Rabegnatar, I N.S. dan O. Praseno. 1993. Estimasi kadar protein optimal dalam pakan buatan untuk pembesaran benih lele (Clarias batrachus) dalam keramba jaring apung. Bull. Penel. Perik. Darat. (12): 86-112.

Shearer, K.D. 1994. Factors affecting the proximate composition of cultured fishes with mphasis on salmo- 
nids. Aquaculture, 199. Amsterdam, Elsevier Science B.V. p. 63-88.

Shell, E.W. 1983. Fish Farming Research. Auburn, Alabama, Auburn University. p. 51-53.

Smith, L.S. 1980. Digestion in teleost fishes dalam FAO/ UNDP. 1980. Fish Feed Technology. Lectures Pre sented at The College of Fisheries, University of Washington, Seattle, Washington, 9 Oktober-15 Desember 1978. Rome, FAO/UNDP. p. 3-18.

Sokal, R.R and F.J. Rohlf. 1973. Introduction to Biostatis tics. W.H. Freeman and Company, San Fransisco. p. 208-217.

Steel, R.G.D. and J.H. Torrie. 1960. Principles and Procedures of Statistics with Special Reference to the Biological. New York, McGraw-Hill Book Company, Inc. p. 107-109.

Stickney, R.A. 1979. Principles of Warmwater Aquaculture. New york, Jonh Willey and Sons. p. 166-168; 183-189.
Strand, F.L. 1976. Physiology. A regulatory system approach. New York, Macmilla Publishing co. p. 3-61; 349-350; 403-405.

Suseno, D. 1983. Studi Perbandingan antara pemijahan alami dengan pemijahan stripping terhadap derajat fertilisasi dan derajat penetasan telur ikan tawes $(P$. gonionotus Blkr.). Bull. Penel. Perik. Dar. (4): 27-34.

Tjahjo, D.W.H. 1991. Kebiasaan pakan komunitas ikan di Waduk Jatiluhur. Bull. Penel. Perik. Darat. Vol. 10 No.2 Juni 1991. Bogor. Balai Penelitian Perikanan Air Tawar. p. 1-8.

Varikul, V. 1980. Summary of freshwater aquaculture in Thailand. Pros. Lok. Nas Teknologi Tepat Guna Bagi Pengembangan Perikanan Budidaya Air Tawar. Bogor, Balai Penelitian Perikanan Air Tawar. p. 313318. 